University at Albany, State University of New York

Scholars Archive

$10-2015$

\title{
Students blogging about politics: A study of students' political engagement and a teacher's pedagogy during a semester-long political blog assignment
}

\author{
Brett Levy \\ University at Albany, State University of New York, bllevy@albany.edu \\ Wayne Journell \\ University of North Carolina at Greensboro \\ Yi He \\ University of Wisconsin-Madison \\ Brian Towns \\ Oregon Alternative School and Integrated Studies
}

Follow this and additional works at: https://scholarsarchive.library.albany.edu/etap_fac_scholar

\section{Recommended Citation}

Levy, Brett; Journell, Wayne; He, Yi; and Towns, Brian, "Students blogging about politics: A study of students' political engagement and a teacher's pedagogy during a semester-long political blog assignment" (2015). Educational Theory and Practice Faculty Scholarship. 15.

https://scholarsarchive.library.albany.edu/etap_fac_scholar/15

This Article is brought to you for free and open access by the Educational Theory and Practice at Scholars Archive. It has been accepted for inclusion in Educational Theory and Practice Faculty Scholarship by an authorized administrator of Scholars Archive. For more information, please contact scholarsarchive@albany.edu. 


\title{
Students Blogging about Politics: A Study of Students' Political Engagement and a Teacher's Pedagogy during a Semester-Long Political Blog Assignment
}

\author{
Brett L. M. Levy \\ University at Albany, State University of New York \\ Wayne Journell \\ University of North Carolina at Greensboro \\ Yi He \\ University of Wisconsin-Madison \\ Brian Towns \\ Oregon Alternative School and Integrated Studies
}

Acknowledgements

The research described in this paper was made possible through the support of the Spencer Foundation (Grant \#201300013). We greatly appreciate their support. In addition, we would like to thank the teacher and students who participated in this study and openly shared their perspectives with us. 


\begin{abstract}
Many scholars have written about the Internet's potential for engaging youth in public issues, but there has been little empirical research on the political engagement outcomes from students' classroom-based use of web 2.0 tools, such as blogs, or the pedagogies involved in designing such experiences. This paper begins to address this gap by analyzing the development of political engagement among several dozen high school students who were required to complete political blogs for their required U.S. government course and by exploring their teacher's pedagogical strategies and challenges. We analyzed data from 22 classroom observations, 15 student interviews, three teacher interviews, and surveys from over 300 students (including a large comparison group) given at the beginning and end of the fall 2012-13 semester. Quantitative and qualitative analyses indicate that students in the blog-focused classes developed greater political interest, internal political efficacy, and self-efficacy for political writing than other students. We also found that the teacher did not actively encourage interactive posting in order to avoid heated exchanges - but that many students expressed an interest in seeing more responses to their online writing. We discuss implications for practice and research.
\end{abstract}

Keywords

civic engagement, pedagogy, curriculum and instruction, blogging, youth leadership, political engagement, civic education, social studies education, teaching

\title{
Article Highlights
}

- One teacher assigned students to create blogs during an election and update them weekly.

- We compared political engagement changes of students in blog-focused classes and other students.

- Students in the blog-focused class had more gains than other students in political interest and internal political efficacy.

- Students in the blog-focused class gained greater confidence for writing about politics.

- Lack of online interactions seemed to limit blogging students' political efficacy gains. 


\section{Introduction}

In many democratic societies, engagement in various political activities, such as voting and contacting officials, has fluctuated widely. During the second half of the twentieth century, for example, voter turnout in Austria, France, Finland, and Switzerland fell by more than ten percentage points (Franklin, 2004), and in the United States, recent voter turnout is below its peak from several decades ago (U.S. Elections Project, 2014). Individuals under 30 years of age tend to participate in political activities at even lower rates than their older counterparts (Bouza, 2014; Center for Information and Research on Civic Learning and Engagement, 2013), so it is important to consider what educators can do to help foster the political engagement of young people.

The purpose of this paper is to examine and analyze the affordances and challenges involved in supporting political engagement among young people through a classroom-based political "blogging" assignment. Over the past decade, blogs commonly defined as "a Web site that contains online personal reflections, comments, and often hyperlinks provided by the writer" (Merriam-Webster, 2014) - have become an increasingly popular technological tool in various fields of education (Kim, 2008), and researchers have begun to explore the opportunities and limitations of student blogging assignments for engaging youth in learning various school subjects (Richardson, 2010). In this paper, we examine one U.S. public high school teacher's use of a political blogging assignment with his two government classes and analyze his students' development of political engagement. There is growing evidence that educational experiences, including online interactions, can bolster young people's likelihood of 
participating in politics (see review below). This paper contributes to our understanding of this process.

\section{Background}

\subsection{Political Engagement}

Our concept of political engagement is based on the foundational frameworks of Eccles' (2005) expectancy-value theory and Bandura's (1997) social cognitive theory. The expectancy-value theory posits that individuals are motivated to perform actions based on (1) expectations of success and (2) valuing the tasks at hand. This theory, which has found empirical support in various educational contexts (e.g., Wigfield \& Eccles, 2000), also comports with political science research indicating that two of the most consistent predictors of political participation (e.g., voting, political activism, and contacting public officials) are political interest (akin to value) and political efficacy (e.g., Becker, 2004; Guyton, 1988; Hirlinger, 1993; Stromback \& Shehata, 2010). Whereas political interest is commonly defined as “citizens' willingness to pay attention to politics at the expense of other endeavors" (Lupia \& Philpot, 2005), political efficacy is conceptualized as the extent to which individuals believe that their actions can influence the government (Beaumont, 2010).

Given the predictive value of political efficacy and interest, researchers in political science and education have also examined the types of experiences that can strengthen these attitudes. Consistent with Bandura's (1997) social cognitive theory, studies have found that political efficacy and interest develop through the interaction of

environmental, behavioral, and psychological processes. For example, research indicates 
that political interest increases when individuals participate in political discussions (Kahne, Crow, \& Lee, 2010) and consume informational news (Stromback \& Shehata, 2010). In addition, when individuals experience positive emotions and then attribute those feelings to a particular type of activity, they tend to become more interested in that type of activity (Silvia, 2006).

Similarly, political efficacy often increases when individuals discuss political issues (Morrell, 2005) or participate in authentic or simulated political processes (Ikeda, Kobayashi, \& Hoshimoto, 2008; Stroupe \& Sabato, 2004). Political scientists often distinguish between internal political efficacy (IPE), one's sense of competence for understanding and acting in the political sphere (through writing and speaking, for example), and external political efficacy (EPE), the belief that the government or society will respond to one's actions (Miller, Miller, \& Schneider, 1980). Nonetheless, studies indicate that teachers' instructional decisions can play an important role in fostering both dimensions of political efficacy as well as political interest (Hahn, 1999; Levy, 2011), and the study described in this paper explores to what extent a technologically rich classroom experience can do so.

\subsection{Web Tools for Civic Engagement}

As the Internet has become an increasingly common tool within classrooms, many scholars have written about its potential for civic education and engagement (e.g., Bennett, 2008; Friedman, 2006; Hicks, Tlou, Lee, Parry, \& Doolittle, 2002; VanFossen \& Berson, 2008; Waring, 2006). The vast majority of that literature, however, has focused on web 1.0 technologies that involve accessing the Internet for information, which can be used as a springboard for civic action, and researchers have only begun to explore the 
potential of more interactive web 2.0 technologies, which can be a powerful medium for civic participation and political interaction.

Web 2.0 tools are defined as Internet-based applications that let users manipulate the web in ways that allow them to share information and respond to information shared by others (Greenhow, Robelia, \& Hughes, 2009; Lankshear \& Knobel, 2006). Among the most popular web 2.0 programs are Facebook and Twitter, and others include blogs, wikis, threaded discussion boards, and file sharing websites. Numerous studies indicate that young people are using these technologies outside of school on a regular basis (Brenner, 2012; Hampton, Goulet, Ranie, \& Purcell, 2011) and that their educational experiences would be more engaging if their teachers integrated such tools into their instruction (DeGennaro, 2008; Spires, Lee, Turner, \& Johnson, 2008). Research also suggests that the inclusion of web 2.0 technologies in classrooms encourages authentic learning and offers a more engaging learning experience for students (e.g., Blankenship, 2009; Heafner \& Friedman, 2008; Krutka \& Milton, 2013; Manfra, Gray, \& Lee, 2010).

While these tools could enhance student engagement in content area learning, they also have the potential to support engagement in issues beyond the classroom. Research and reporting from throughout the world suggests that web 2.0 technologies have the potential to entice the often politically disengaged youth demographic into becoming more politically engaged, and may be stimulating a new wave of political activism (e.g., Lee, Shah, \& McLeod, 2012; Levine, 2008; Lim, 2013; Zhang, 2013). Interactions on Facebook and Twitter, for example, have been credited with facilitating higher electoral turnout (Bond, Fariss, Jones, Kramer, Marlow, Settle, \& Fowler, 2012; Vitak, Zube, Smock, Carr, Ellison, \& Lampe, 2011), exposure to diverse viewpoints (Gil 
de Zuniga \& Valenzuela, 2011; Kahne, Middaugh, Less, \& Feezell, 2012), and protest activity (Huang, 2011; Lim, 2012). Meanwhile, some scholars have argued that when students create and read one another's blogs, they are exposed to a wide variety of viewpoints (Hostetler, 2012; Drake \& Drake, 2014).

Despite this potential, few studies have examined how schools have used web 2.0 technologies as tools to foster civic engagement. To begin to address this research gap, this study explores a semester-long classroom assignment that required students to create political blogs about the 2012 presidential election in the US (between Barack Obama and Mitt Romney) and its aftermath. Although blogging in educational contexts is hardly a novel concept (Kim, 2008), few studies have analyzed the relationship between active blogging and students' political engagement. In this paper, we analyze how one teacher structured a student blogging assignment, how the blogging experience supported students' political engagement, and the challenges associated with this process.

\section{Research Questions}

The main questions guiding this research are as follows:

a. How does a government teacher structure and scaffold a political blogging assignment for high school students?

b. In what ways and to what extent do students become politically engaged when they create blogs about a major election?

c. What challenges are involved for students and teachers when teaching and learning about political blogging? 


\section{Method}

\subsection{Data Sample and Study Context}

Our data included quantitative and qualitative data from adolescents and one teacher in the Midwestern region of the United States. Several dozen of these students participated in a course that required them to complete a political blog, and the other participants did not. The first and fourth author collected these data in the fall semester of the 2012-13 school year as part of a larger study of youth political engagement during the US presidential election. Quantitative data included questionnaire responses from over 300 students between the ages of 15 and 18 who were enrolled in four high schools, about two-thirds of whom were taking a course in government or something closely related (e.g., political science or social issues). At two of these schools, including the school with a blogging assignment, government was a required course. About half the sample was female, and approximately 25 percent were non-white (mostly AfricanAmerican or Latino/a).

The focal participants for this study included one government teacher, Mr. Robinson, and students in his two government classes at Reagan High School (all names of individuals and schools are pseudonyms). Students at Reagan were required to complete a government course in order to graduate and had the option of taking either a regular government course or an Advanced Placement course. Mr. Robinson taught the regular government course. Reagan High School had several well-maintained computer labs with consistent Internet access. Altogether, the first and fourth author observed 22 of Mr. Robinson's class sessions, interviewed 15 students (often more than once), and interviewed Mr. Robinson several times. 
The blog assignment and the process of blogging were new to Mr. Robinson's government classes for the 2012-13 school year. As a middle-aged veteran teacher with over ten years of classroom experience, he expressed excitement about the challenge. Though he had used blogs as a part of his contemporary issues course the previous year, this particular project was novel for both the students and the teacher. As Robinson introduced the assignment, only one student admitted to having created a blog in the past, and this student clarified that he was not an expert.

\subsection{Measures and Procedures}

To explore changes in students' political engagement, our questionnaires measured aspects of their political interest and political efficacy at the beginning and end of their government course - in September 2012 (Time 1) and January 2013 (Time 2). Questionnaire items were adapted from the American National Election Study (Craig, Niemi, \& Silver, 1990), the Civic Education Study (Torney-Purta, Lehmann, Oswald, \& Schultz, 2001), and studies of the expectancy-value model (Wigfield \& Eccles, 2000). In addition, we asked students their ethnicities, grade point averages, mothers' levels of education, and web access at home. (For a list of key items, see Appendix A.)

Our qualitative data included transcripts from one-on-one interviews with students, during which we asked questions about their political interest, political efficacy, and experiences with blogging. To explore teachers' instructional strategies, we recorded detailed field notes during our classroom observations, keeping track of the teacher's directions and framing, students' interactions, and the time spent on different activities. We also conducted three interviews with Mr. Robinson, each of which lasted between 15 and 25 minutes, during which we asked him about the goals, strategies, and challenges 
related to his work teaching with political blogs.

\subsection{Data Analysis}

To analyze our questionnaire data, we conducted a variety of quantitative analyses. First, we examined demographic data and conducted independent samples ttests to identify possible differences between students in the blog-focused class and other students in the sample. Then, to identify items most closely associated with political interest and efficacy, we conducted principal component analysis using varimax rotation. Through exploratory factor analysis, we examined relationships among the items and found that there were no cross-loadings greater than 0.3 . Then to create our factors, we calculated the composite values of the related items.

Next we conducted a series of ordinary least squares regression analyses to explore the extent to which different factors and variables, including participating in the blog-focused class, related to changes in students' political interest and efficacy. In addition to exploring changes to these dimensions, we explored changes to one aspect of students' internal political efficacy especially relevant to blogging, i.e. their self-efficacy for writing about politics (SEWAP). Because our participants included both focal students (those in the blog-focused class) and a comparison group (which included both students who were and were not in government courses), we expected that political engagement changes resulting from contextual issues, such as media coverage during an election, would have similar effects on the two groups and would not distort our comparisons of these groups. Furthermore, for all of these regression analyses, we controlled for various background variables, including race, sex, GPA, enrollment in a government course, and initial levels of political engagement. To keep the number of 
independent variables within reasonable limits, we combined mothers' education levels

and home Internet access into one composite variable, which we labeled home education environment.

To analyze our qualitative data, we transcribed our interviews and conducted several rounds of coding to categorize students' and teachers' comments and interactions. For example, some comments indicated a clear relationship between the blog activity and aspects of students' internal political efficacy, such as self-efficacy for political knowledge, whereas other comments explored aspects of the blogging activity that students disliked. In cases when categories had similar meanings, we collapsed these codes. Analyses of our observation data involved a similar process. We read through our observation field notes, coded for various types of activities, scaffolds, and interactions and eventually collapsed these codes in order to generate a clear, concise, and useful description of the teacher's strategies.

\section{Findings}

\subsection{Characteristics of Blog-Focused Class and Comparison Group}

Results of our exploratory data analysis indicated that there were some demographic differences between students in the blog-focused class and the rest of the sample. Although both groups included similar proportions of female and high-achieving students, the students in the blog-focused class were more likely to be white and have mothers who graduated from college than the comparison group (See Table 1). Also, students in the latter group were slightly less likely to have access to the Internet at home, but the vast majority of both groups had regular Internet access. 
Table 1

Description of Sample $(N=309)$

\begin{tabular}{|l|c|c|c|}
\hline Characteristics & $\begin{array}{c}\text { Robinson's } \\
\text { Students } \\
(\mathrm{N}=54)\end{array}$ & $\begin{array}{c}\text { Comparison } \\
\text { Group } \\
(\mathrm{N}=255)\end{array}$ & $\begin{array}{c}\text { Full } \\
\text { Sample } \\
(\mathrm{N}=309)\end{array}$ \\
\hline \% Female & 48 & 53 & 51 \\
\hline$\%$ Non-white Minority & $17 *$ & 25 & 25 \\
\hline$\%$ GPA 3.5 or higher & 53 & 57 & 55 \\
\hline \% Mothers Graduated College & $64 * * *$ & 52 & 53 \\
\hline$\%$ No Home Web Access & $0 \sim$ & 3 & 3 \\
\hline$\%$ Enrolled in Gov-Related Course & $100^{* * *}$ & 45 & 50 \\
\hline
\end{tabular}

$* * * \mathrm{p}<.001, * * \mathrm{p}<.01, * \mathrm{p}<.05, \sim \mathrm{p}<.1$ (Indicating significant differences from comparison group)

\subsection{Teacher's Strategies and Goals}

On the first day of school, Mr. Robinson introduced the assignment by describing the purpose of the assignment and by outlining the general expectations for students' entries. He explained that the purpose of the blog would be to communicate one's viewpoint and generate interest and participation in politics, and he let the students know that they would be expected to complete a new blog entry each week. The blogging process, he explained, would consist of informal writing, and he reiterated the fact that the series of entries would count as one of two summative assessments for the course. In an interview, he explained why he decided to make this assignment so central to the students' work for the semester:

If you start out with a textbook, you're going to lose them right away. So what you have to do, what we have to do, I think, as teachers is give them an opportunity to see an issue, or something that's taking place that is currently happening, and that they can get into, that they can dive into and then from there, 
be able to see the nuts and bolts of how government works. And I think there has to be a forum where they can discuss it, whether it be through a blog, which we're trying to do this semester ... and give them an opportunity to be able to not only say what they think, but also find a way to be able to back it up with factual evidence from reliable sources (Interview, September 20, 2012).

Students were expected to complete each blog entry by midnight the ensuing Sunday, and they would be graded, with a rubric, on a scale of one to four. An entry consisting of only opinion would earn a mark of one or two; an entry with some evidence would earn a two or three; and an entry with a mix of evidence and insight would earn a four. Robinson stressed that a lack of evidence in one's posts would lead to a lower grade. In addition, he provided a list of items students might use to support their opinions, such as quotes, facts, descriptions of events, something from articles or other reading during the week, or anything else that seemed reliable.

Our observations suggest that the students fairly quickly understood the assignment and the wide range of topics, but throughout the semester, Robinson found it necessary to reinforce a few points, such as the importance of using reliable evidence and sources to support their arguments. Students' blog topics included students' responses to party convention speeches, political movements, campaign finance, presidential debates, and discussions of the post-election statistics. Almost three weeks into the semester, about $75 \%$ of the students were regularly completing their entries on time, and Mr. Robinson advised students who were falling behind to talk with him.

At the end of the fifth week, he revisited the idea of a quality entry by showing two examples of student work and asking students to rate the entries on the rubric scale of 
1-4. After reading the entries aloud to the class, he pointed to the lack of evidence in one and sufficient evidence in the other. During this episode, students appeared attentive to Mr. Robinson as he presented the examples, and they responded with a show of hands when he asked them to indicate their own ratings of the excerpts read aloud.

\subsection{Students' Development of Political Engagement}

Results of our quantitative and qualitative analysis indicate that blogging experiences were positively related to students' development of political interest, internal political efficacy, and self-efficacy for writing about politics - but not to students' development of external political efficacy (See Table 2). Specifically, students in the blog-focused course had political interest at Time 2 that was about .08 standard deviations higher than that of other students, controlling for race, sex, GPA, grade level, home education environment, enrollment in a government-related course, and political interest at Time $1(\mathrm{p}<.05)$. Our qualitative data support and help to explain these findings. One high school senior Karen said that she found the blogging assignments to be engaging: "I really like it. It's nice that it's not too strict . . . because you can add your own opinions in there and it's fun." (Interview, November 16, 2012). Her classmate Molly agreed, emphasizing that the chance to share her views "on the different issues and still show that you know the topic" was more enjoyable than a typical school assessment, "like a multiple choice test" (Interview, January 18, 2013). Such comments by Karen, Molly, and other students suggest that the opportunity to share their perspectives in an open-ended way enabled them to develop positive associations with political learning.

Likewise, students who took the blog-focused course had higher Time 2 internal political efficacy than other students, controlling for an array of background variables and 
initial IPE levels $(\mathrm{p}<.01) .{ }^{1}$ In one interview, Aaron explained that the blogging activities had helped him to better understand the issues that he and his classmates had explored in class (Interview, October 12, 2012). Our analyses also found that students involved in blogging developed more self-efficacy for writing about politics. Controlling for race, sex, GPA, home education environment, enrollment in a government-related course, and initial levels of SEWAP, students in the blog-focused class had Time 2 SEWAP that was about .18 standard deviations higher than that of other students ( $p<.001)$. High school senior Andrea explained her growth in political writing self-efficacy this way:

I've never really been big on writing and like, blogging type thing. I feel like it's getting easier, though, because I have to do it more. It's kind of nice to be able to share my thoughts and like get it all down on paper $[$ sic $]$... That was kind of cool (Interview, November 16, 2012).

Like many other students, by halfway through the semester - after having completed numerous blog posts for the class - Andrea had become much more comfortable writing about political issues.

Thus, students in the blog-focused class developed greater political interest and confidence in their political skills and knowledge (i.e., IPE) than even their peers in other government courses, many of whom had more face-to-face interactive discussions (based on our observations of those classrooms). Nonetheless, we also found that students in the blog-focused class had Time 2 external political efficacy that was not significantly

\footnotetext{
${ }^{1}$ As Appendix A indicates, our IPE composite measure includes the SEWAP item. We also created an IPE composite measure that excluded the SEWAP item and conducted the same regression analysis. Results indicated that the blog-focused class still had a marginally significant relationship to IPE at Time 2, controlling for the same background variables and IPE at Time 1.
} 
different from that of other students, controlling for race, sex, GPA, home education

environment, enrollment in a government course, and EPE at Time 1.

Table 2

Standardized Coefficients (and Standard Errors) of OLS Regression Models Examining Changes in Students' Political Engagement $(N=309)$

\begin{tabular}{|c|c|c|c|c|}
\hline $\begin{array}{l}\text { Independent } \\
\text { Variables }\end{array}$ & $\begin{array}{c}\text { Political Interest, } \\
\text { Time } 2 \\
(\mathrm{~N}=309) \\
\end{array}$ & $\begin{array}{c}\text { IPE, Time } 2 \\
(\mathbf{N}=304)\end{array}$ & $\begin{array}{c}\text { SEWAP, Time } \\
2 \\
(\mathrm{~N}=305)\end{array}$ & $\begin{array}{c}\text { EPE, Time } 2 \\
(\mathrm{~N}=302)\end{array}$ \\
\hline Home Ed Environ. & $-.004(.021)$ & $.014(.019)$ & $.029(.031)$ & $.057(.013)$ \\
\hline Non-white Minority & $-.024(.094)$ & $-.031(.086)$ & $-.025(.140)$ & $.026(.101)$ \\
\hline Female & $-.027(.079)$ & $-.065(.073) \sim$ & $-.101(.118)^{*}$ & $-.004(.085)$ \\
\hline High GPA (3.5+) & $100(.087)^{* *}$ & $.136(.080)^{* *}$ & $.223(.129)^{* * *}$ & $-.002(-.095)$ \\
\hline Government Class & $-.034(.085)$ & $.127(.077)^{* *}$ & $.114(.125)^{*}$ & $.054(.090)^{* * *}$ \\
\hline Pol. Interest, Time 1 & $.781(.033) * * *$ & -- & -- & -- \\
\hline IPE, Time 1 & -- & $.722(.036)^{* * *}$ & -- & -- \\
\hline SEWAP, Time 1 & -- & -- & $.517(.044) * * *$ & -- \\
\hline EPE, Time 1 & -- & -- & -- & $.682(.047)^{* * *}$ \\
\hline Blog-Focused Class & $.077(.130)^{*}$ & $.098(.119)^{* *}$ & $.176(.195)^{* * *}$ & $-.062(.047)$ \\
\hline Constant & $1.225(.189) * * *$ & $.860(.187)^{* * *}$ & $1.376(.272)^{* * *}$ & $.751(.206)$ \\
\hline Adjusted $\mathrm{R}^{2}$ & $.648 * * *$ & $.628 * * *$ & $.412 * * *$ & $.480 * * *$ \\
\hline
\end{tabular}

\subsection{Challenges of Teaching and Learning with Blogs}

Despite the generally positive political engagement outcomes for students in the blog-focused course, there were numerous challenges involved in teaching and learning related to these activities. First, students who committed substantial thought and energy to their work often became frustrated by the lack of responses to their blog posts. More than two full months into the semester, student Avery told me that only one or her friends and the teacher had read her blog. Mr. Robinson encouraged students to look at one another's blogs and write responses, but this was not required and quite rare. Meanwhile, some students indicated that even the teacher seemed uninterested in their posts. As Nathan told us, "It feels more like just an assignment, like [Mr. Robinson] will ... give you a grade more than like he'll give you feedback ..." (Interview, November 16, 2012). 
Although Mr. Robinson graded every post and occasionally wrote comments on them, providing thoughtful responses to over 50 writing assignments each week (in addition to managing other classes) would have required a tremendous amount of time.

Despite this trend of limited online interaction, having students share their ideas widely and receive substantive responses was one of Mr. Robinson's initial purposes, as he explained early in the semester:

I think it's more exciting [if] they can have other people that they can choose that can access their blog, so there is somebody outside of the instructor, myself, reviewing it. So you have other students that are looking at their work, and if they want to make it accessible to people outside of the class, even in the community, whether it be family members and, you know, I think that's what we would like to get to. [But] I think there's anxiety among some students about having anybody else take a look at their work, so it's a big step to say I'm going to pick four people in the class, or four people at this school that are going to take a look at my blog and hopefully respond to it (Interview, September 20, 2012).

Although Mr. Robinson was initially enthusiastic about having students interact with one another's blogs, his concerns about students' discomfort sharing their political ideas publically appeared to contribute to his decision not to require students to respond to others' posts.

As he told us towards the end of the semester, "Getting [students] to feel comfortable to be able to agree to disagree and to be able to still express their opinions is a challenge" (Interview, December 13, 2012). The heated nature of some face-to-face class discussions, especially during the presidential election season, in which students 
were exposed to numerous political ads and partisan talk beyond the classroom, seemed to alter his initial plans for the blog. He expressed concerns especially for the liberal students in his class, who, in his view, may have felt intimidated by the strong conservative slant among the class as a whole. In addition to being deterred by the political context, making even more assignments for students typically requires a teacher to keep track of these activities, which can take substantial amounts of time, as Mr. Robinson acknowledged. Thus, whereas students desired more interactive experiences online, the teacher was hesitant to require this for a variety of reasons.

\section{Discussion}

Overall, this study's findings suggest that when students create and develop politically oriented blogs, they are likely to become more politically engaged, at least in the short-term. Specifically, we found that over the course of one semester, political blog assignments supported high school students' increased political interest, internal political efficacy, and self-efficacy for political writing. However, such assignments did not influence students' external political efficacy, and this may be related to the blogs' disconnection from an authentic audience, such as peers or the broader society. Whereas prior research indicates that blogging can help students to become engaged in learning content in various domains, this study provides unique insights into how such activities can help to support students' interest in and self-efficacy for addressing public issues. Our findings have important implications for practice and research related to how modern technologies can be used in educational settings to support youth political engagement. 
First, the results of our analyses suggest that teachers who are interested in supporting their students' political interest and efficacy could make progress towards these goals by assigning their students to create and develop blogs about political issues. As prior research indicates, students often experience increased civic and political engagement through opportunities to express and exchange political ideas with their peers (Hess, 2009; Parker \& Hess, 2001), and if structured appropriately, blogs can create such a venue. In this study, many students enjoyed the opportunity to express their political perspectives. However, Mr. Robinson did not require students to respond to one another's blog posts, and students seemed dissatisfied with their apparent lack of an authentic audience. Levine (2008) has argued that school-based online civic engagement efforts often suffer due to this problem, and he suggests that teachers help students to connect with potential readers or viewers, whether peers or individuals beyond the schoolhouse walls. Such audiences might respond not only through comments but also through rating writers' posts (in various categories), forwarding them, or posting relevant articles. Future research should examine the political and/or civic engagement outcomes of assignments in political blogging and other politically oriented web 2.0 activities that have students reach a clear and responsive audience.

Despite the potential of interactive online environments, some teachers, such as Mr. Robinson, may be hesitant to encourage direct exchanges among students due to the potential for rancorous argument and hostile disagreement. This is a valid concern, particularly in polarized political environments, such as the United States (Abramowitz \& Saunders, 2008; McAvoy \& Hess, 2013). However, in online courses in various fields, educators have helped students to interact kindly and thoughtfully by encouraging them 
to follow the norms of "Netiquette" (Connor, n.d.). While helping to foster content-rich exchanges, such practices could also help students learn to consider each other's ideas, which can be challenging in crowded online environments. Studies in the future could explore different ways of teaching students appropriate online communication norms in digital political environments and the effects of different approaches.

Furthermore, one of this study's most powerful findings was the large extent to which blogging students experienced increased self-efficacy for writing about politics. Prior research suggests that practicing discrete skills supports self-efficacy for those skills and that this greater self-efficacy in turn leads to increased engagement for related tasks (Bandura, 1997). Thus, it is possible that the students in this study, due to their higher self-efficacy for writing about politics, subsequently wrote more often about politics and developed greater writing skills. Further studies should examine the extent to which students who engage in political blogging for class continue such writing beyond the assignment - and the ways that such experiences might influence their writing and analytical skills. Similarly, future research should examine the extent to which the civic and political attitudes that students develop through classroom-based political experiences change, or remain stable, after those structured experiences have ended.

\section{Conclusion}

Guiding students through the process of creating, developing, and maintaining political blogs can be a powerful way to prepare young people to communicate their perspectives and become politically engaged. Although there are challenges involved in such pedagogical practices, online tools offer enormous potential for enabling students to develop their public voices and to begin participating in democratic exchanges. Given 
that many youth are not highly engaged in political activities (Levinson, 2012), we hope that researchers and educators continue to explore these possibilities in diverse educational settings. 


\section{References}

Abramowitz, A. \& Saunders, K. (2008). Is polarization a myth? The Journal of Politics, $70(2), 542-555$

Beaumont, E. (2010). In L. Sherrod, J. Torney-Purta, \& C. Flanagan (Eds.), Handbook of Research on Civic Engagement in Youth. Wiley.

Bandura, A. (1997). Self-efficacy: The exercise of control. New York, NY: Freeman.

Becker, R. (2005). Political efficacy and voter turnout in East and West Germany. Swiss Political Science Review, 11(1), 57-86.

Bond, R. M., Fariss, C. J., Jones, Jason J., Kramer, A. D. I., Marlow, C., Settle, J. E., \& Fowler, J. H. (2012). A 61-million-person experiment in social influence and political mobilization. Nature, 489 (7418), 295-8.

Bouza, L. (2014). Addressing youth absenteeism in European elections. League of Young Voters in Europe. Retrieved from: http://www.youthforum.org/assets/2014/02/YFJLYV_StudyOnYouthAbsenteeism_WEB.pdf

Center for Information and Research on Civic Learning and Engagement (2013). The youth vote in 2012. Circle Fact Sheet. Retrieved from http://www.civicyouth.org/wpcontent/uploads/2013/05/CIRCLE_2013FS_outhVoting2012FINAL.pdf

Connor, P. (n.d.). Netiquette: Ground rules for online discussions. Retrieved online 12 Sept 2014 at http://teaching.colostate.edu/tips/tip.cfm?tipid=128

Craig, S. C., Niemi, R. G., \& Silver, G. E. (1990). Political efficacy and trust: A report on the NES pilot study items. Political Behavior, 12(3), 289-314.

Drake, J. P., \& Drake, J. L. (2014). One blog at a time, students slog through immigration and complex issues. Ohio Social Studies Review, 51(1), 52-63.

Eccles, J. S. (2005). Subjective task value and the Eccles et al. model of achievementrelated choices. In A. J. Elliot \& C. S. Dweck (Eds.). Handbook of Competence and Motivation. New York, NY: Guilford Press.

Franklin, M. N. (2004). Voter turnout and the dynamics of electoral competition in established democracies since 1945. Cambridge, UK: Cambridge University Press.

Garden, M. (2011). Defining blog: A fool's errand or a necessary undertaking. Journalism, 13, 483-499. 
Gil de Zuniga, H., \& Valenzuela, S. (2012). The mediating path to a stronger citizenship: Online and offline networks, weak ties, and civic engagement. Communication Research, 38(3), 397-321.

Guyton, E. (1988). Critical thinking and political participation: Development and assessment of a causal model. Theory and Research in Social Education, 16(1), 23-49.

Hahn, C. L. (1999). Citizenship education: An empirical study of policy, practices, and outcomes. Oxford Review of Education, 25(1-2), 231-250.

Hess, D. E. (2009). Controversy in the classroom: The democratic power of discussion. New York, NY: Routledge.

Hirlinger, M. W. (1992). Citizen-initiated contacting of local government officials: A multivariate explanation. The Journal of Politics, 54(2), 553-564.

Hostetler, A. L. (2012). Democratic use of blogs and online discussion boards in social studies education. Social Education, 76, 100-104.

Ikeda, K., Kobayashi, T., \& Hoshimoto, M. (2008). Does political participation make a difference? The relationship between political choice, civic engagement and political efficacy. Electoral Studies, 27(1), 77-88.

Kahne, J., Crow, D., \& Lee, N. (2010). Discussion-based and experiential high school curricula: Their differential impact on civic and political outcomes. Unpublished manuscript.

Kahne, J., Middaugh, E., Lee, N., \& Feezell, J. T. (2012). Youth online activity and exposure to diverse perspectives. New Media \& Society, 14(3), 492-512.

Kim, H. N. (2008). The phenomenon of blogs and theoretical model of blog use in educational contexts. Computers \& Education, 51, 1342-1352.

Kirby, E. H., \& Kawashima-Ginsberg, K. (2009, August 17). Youth vote in 2008. Center for Information \& Research on Civic Learning and Engagement. Retrieved October 12, 2009, from http://www.civicyouth.org/PopUps/FactSheets/FS_youth_Voting_2008_updated 6.22.pdf

Lim. M. (2012). Clicks, cabs, and coffee houses: Social media and oppositional movements in Egypt, 2004-2011. Journal of Communication, 62, 231-248.

Levy, B. L. M. (2011). Fostering cautious political efficacy through civic advocacy projects: A mixed methods case study of an innovative high school class. Theory and Research in Social Education, 39(2), 238-277. 
Levine, P. (2008). A public voice for youth: The audience problem in digital media and civic education. In Bennett, L. (Ed.). Civic Life Online: Learning How Digital Media Can Engage Youth (pp. 119-38). Cambridge, MA: MIT Press.

Levinson, M. (2012). No citizen left behind. Cambridge, MA: Harvard University Press.

Lupia, A. \& Philpot, T.S. (2005). Views from inside the Net: How websites affect young adults' political interest. Journal of Politics, 67(4), 1122-1142.

McAvoy, P., \& Hess, D. (2013). Classroom deliberation in an era of political polarization. Curriculum Inquiry, 43, 14-47.

Morrell, M. E. (2005). Deliberation, democratic decision-making and internal political efficacy. Political Behavior, 27(1), 49-69.

Parker, W. \& Hess, D. (2001). Teaching with and for discussion. Teaching and Teacher Education, 17, 273-289.

Richardson, W. (2010). Blogs, wikis, podcasts, and other powerful web tools for the classroom $\left(3^{\text {rd }}\right.$ ed.). Thousand Oaks, CA: Corwin.

Silvia, P. J. (2006). Exploring the psychology of interest. Oxford, UK: Oxford UP.

Stromback, J. \& Shehata, A. (2010). Media malaise or virtuous circle? Exploring the causal relationships between news media exposure, political news attention and political interest. European Journal of Political Research, 49, 575-597.

Torney-Purta, J., Lehmann, R., Oswald, H. \& Schultz, W. (2001). Citizenship and education in twenty-eight countries. Amsterdam, Netherlands: International Association for the Evaluation of Educational Achievement (IEA).

United States Elections Project (2014). National general election VEP turnout rates, 1789-Present. Retrieved from http://www.electproject.org/national-1789-present.

Vitak, F., Zube, P., Smock, A., Carr, C. t., Ellison, N., \& Lampe, C. (2011). It's complicated: Facebook users' political participation in the 2008 election. Cyberpsychology, Behavior, and Social Networking, 14(3), 107-114.

Wigfield, A., \& Eccles, J. S. (2000). Expectancy-value theory of achievement motivation. Contemporary Educational Psychology, 25, 68-81. 


\section{APPENDIX A: KEY QUESTIONNAIRE ITEMS}

Table A1

Items in Political Engagement Composite Variables

\begin{tabular}{|c|c|c|}
\hline Factor & Variable Question/Statement & $\begin{array}{l}\text { Response Choices } \\
\text { (six levels) }\end{array}$ \\
\hline \multirow[t]{2}{*}{ Political Interest } & $\begin{array}{l}\text { Generally speaking, how interested are you in political issues or } \\
\text { current events? }\end{array}$ & \multirow[t]{2}{*}{$\begin{array}{l}\text { Not at all interested - } \\
\text { Extremely interested }\end{array}$} \\
\hline & $\begin{array}{l}\text { Generally speaking, how interested are you in learning about political } \\
\text { campaigns? }\end{array}$ & \\
\hline \multirow{3}{*}{$\begin{array}{l}\text { Cronbach's } \\
\text { Alphas: } \\
.923 \text { (Time 1) } \\
.916 \text { (Time 2) }\end{array}$} & $\begin{array}{l}\text { Compared to most of your other activities, how useful is learning } \\
\text { about political issues? }\end{array}$ & $\begin{array}{l}\text { Very useless - } \\
\text { Very useful }\end{array}$ \\
\hline & For me, understanding political issues is: & $\begin{array}{l}\text { Not at all important - } \\
\text { Extremely important }\end{array}$ \\
\hline & How much do you like learning about political issues? & $\begin{array}{l}\text { Dislike extremely - } \\
\text { Like extremely }\end{array}$ \\
\hline $\begin{array}{l}\text { Internal Political } \\
\text { Efficacy (IPE) } \\
\text { Cronbach's } \\
\text { Alphas: } \\
.871 \text { (Time 1) } \\
.896 \text { (Time 2) } \\
\text { Cronbach's Alphas } \\
\text { w/o SEWAP: } \\
.849 \text { (Time 1) } \\
.871 \text { (Time 2) }\end{array}$ & $\begin{array}{l}\text { I feel that I have a pretty good understanding of the important } \\
\text { political issues facing our country. } \\
\text { I feel that I have a pretty good understanding of the important } \\
\text { political issues facing our world. } \\
\text { I am confident that I can construct good arguments about political } \\
\text { issues. } \\
\text { I often don't feel sure of myself when talking with other people about } \\
\text { politics and government. [reverse coded] } \\
\text { I can write clearly about political issues. [SEWAP] }\end{array}$ & $\begin{array}{l}\text { Strongly Disagree - } \\
\text { Strongly Agree }\end{array}$ \\
\hline $\begin{array}{l}\text { External Political } \\
\text { Efficacy (EPE) } \\
\text { Cronbach's } \\
\text { Alphas: } \\
.865 \text { (Time 1) } \\
.891 \text { (Time 2) }\end{array}$ & $\begin{array}{l}\text { Public officials care what people like me think. } \\
\text { If there's a serious local problem, I can do something to get local } \\
\text { elected officials to improve the situation. } \\
\text { If there's a serious problem in my state, I can do something to get } \\
\text { state elected officials to improve the situation. } \\
\text { If there's a serious national problem, I can do something to get federal } \\
\text { elected officials to improve the situation. } \\
\text { I can do something to influence who wins a local election. } \\
\text { I can do something to influence who wins a state election. }\end{array}$ & $\begin{array}{l}\text { Strongly Disagree - } \\
\text { Strongly Agree }\end{array}$ \\
\hline
\end{tabular}

Table A2

Demographic Items

\begin{tabular}{|l|l|l|}
\hline Variable Label & \multicolumn{1}{|c|}{ Variable Question/Statement } \\
Education Level & $\begin{array}{l}\text { To the best of your knowledge, what is your mother's (or } \\
\text { stepmother's or female guardian's) highest level of education? }\end{array}$ & $\begin{array}{l}\text { Middle School - } \\
\text { Completed Graduate Degree } \\
\text { (six choices) }\end{array}$ \\
\hline Sex & Do you identify as male or female? & Male/Female \\
\hline Ethnicity & How would you describe your ethnicity? & $\begin{array}{l}\text { Black/African-American, } \\
\text { White or Caucasian, } \\
\text { Asian-American/Pac Islander, } \\
\text { Native American, } \\
\text { Bi/Multi-Racial, } \\
\text { Latino or Latina, } \\
\text { Other }\end{array}$ \\
\hline GPA & What is your approximate grade point average? & Less than 2.0 - 4.0 (6 choices) \\
\hline $\begin{array}{l}\text { Home Web } \\
\text { Access }\end{array}$ & $\begin{array}{l}\text { In your home, approximately how many computers do you } \\
\text { have with Internet access? }\end{array}$ & 0, 1, 2, 3 or more \\
\hline
\end{tabular}

